\title{
PECULIARITIES OF TRAINING OF HIGHER SCHOOL TEACHERS IN MAGISTRACY IN THE UNITED STATES
}

Batechko Nina, doctor of pedagogical sciences, leading researcher of Scientific-Research Laboratory of Educology, Borys Grinchenko Kyiv University, 13-b Tymoshenko Str., 04212 Kyiv, Ukraine, n.batechko@kubg.edu.ua

The peculiarities of training of master's degree students - future teachers of higher educational institutions in the United States are grounded in the article. The main tendencies of the US higher education development and their impact on the organization of training of master's degree students - future teachers of higher school are noted. The basic vectors of the research in pedagogical theory on the problems of American higher school and basic directions of comparative pedagogical research are outlined. The general tendencies of master training in the US and their interdependence with the training process for future higher school teachers in the US are analyzed. The examples of introducing of innovative forms and methods of training of future teachers of higher educational institutions in the conditions of magistracy are provided. Important areas of implementation of the American experience in training of master's degree students in higher school in Ukraine are determined.

Key words: magistracy, master's degree student, higher school teacher.

Стаття надійшла до редакції 06.10.2016

Прийнято до друку 27.10.2016

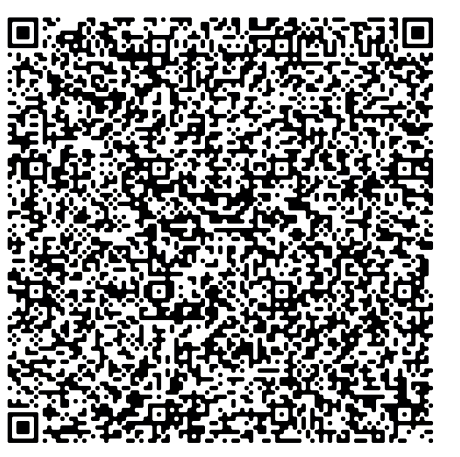

УДК 378

\section{STYUDENTS TRAINING TENDENCY IN THE EUROPEAN UNION: LEGAL ASPECT}

The article presents the current trends in the preparation of students in higher education in the EU. These trends are identified on the basis of the analysis of legal documents (legal acts of primary and secondary law), which reflect the EU response to contemporary global changes in education: globalization and marketization. These processes require from higher education to provide new approaches to the training of students in accordance with labour market demands. With this in mind, the author focuses on the process of teacher training as well.

Keyzords: higher education; labour market; legal acts; training of students; the EU.

Introduction. The processes of globalization and marketization have direct impact on policy in the field of higher education. The study of the European Commission reports (The European Higher Education Area in 2015, 2014; Structural Indicators for Monitoring Education and Training Systems in Europe, 2015) indicates that the main aim of the modernization of higher education and the labour market in the EU is to improve the employment prospects of graduates. In this process there are two main strategic directions. The first area focuses on the labour market demand - which should be considered by HEIs. The second - selects employable graduates and provides a supply-side perspective: what universities have to reach for graduates, for example, provide graduates a set of relevant skills and competencies. In this regard, most of the discus- sions are focused on the role of universities and how they should function in the knowledge society of the XXI century.

Statement of the problem. In order to overcome the economic crisis the EU chose strategy «Europe 2020», this means the European movement towards highly-developed economy, which needs highly skilled workers. Accordingly, the future success of the EU economy depends on effective transition of graduates from higher education and training to employment, which is possible only if the graduates have appropriate training for employers' demands. This situation is changing not only the role of universities in general, but the training process as well, where the function of the teacher will win a significant role. Teachers at universities can play a crucial role in the formation of the 
younger generation and in preparing them for future careers in society. This profession performs a vital function in the development of human potential and shaping future generations. That is why the EU is considering the role of teachers and the development of their careers as key priorities as outlined in the official documents of the European Commission and regulatory documents of the EU. Study of the EU experience in training teachers is an important practical aspect of the European integration of Ukraine where this problem is of great interest (Ognevyuk V., Sysoieva S., 2015). This aspect becomes clear only in the context of the analysis of modern approaches to training graduates in the EU. Accordingly, the purpose of this article is to identify current trends in students training in the EU based on research and analysis of legal documents of the EU.

Presentation of the work. The reaction of higher education to global changes in the world was reflected in important declarations, treaties and acts of secondary law, which formed the legal basis for cooperation between higher education and labor market in the EU. The Bologna process is considered to be a strategic European government response to the current economic and geopolitical situation. Today's continuation of the defined objectives of the Bologna process became the strategy «Europe 2020», which clearly identified two interrelated policies - support of growth and jobs and programs for the modernization of higher education in Europe. Thus, the Bologna process, the Lisbon strategy, the strategy «Europe 2020» played a significant role in providing factual powers to create legislation on policies for cooperation between higher education and labour market at EU level that directly affected the process of training.

But the legal basis for the early formation of a modern policy of training of students, which is based on the interaction of higher education with labor market, can be considered the Resolutions of the Council and of the Ministers of Education in 1976, 1980, 1982 and 1985 «Measures to be taken to improve the preparation of young people for work and to facilitate their transition from education to working life».

Given the interest of the European Parliament and the Economic and Social Committee to strengthen cooperation between higher education and youth employment, a Resolution of the Council and Ministers of Education of 13 December 1976 was adopted. It was aimed to strengthen consultation and coordination between education and training, job placement and training to facilitate the preparation of young people for their entry into working life. The resolution stressed the need for cooperation between those who are responsible for education, guidance, training and job placement (Resolution of the Council of 13 December 1976).

In the next Resolution of the Council of 15 January 1980 it was decided to run a pilot training program to improve the preparation of young people for work and to facilitate their transition from education to working life (Resolution of the Council of 15 January 1980). In the Resolution of the Council of 12 July 1982 it was first stressed the development of practical cooperation between education, employment and social institutions in order to provide graduates with working experience (Resolution of the Council of 12 July 1982).

The Council Resolution of 17 December 1999 «Into the new millennium» became the result of the previous ones where it was highlighted the need for unification of the role of education and training with employment policies; the development of quality education and training at all levels; mobility, including recognition of qualifications and periods of study (Council Resolution of 17 December 1999).

According to the Treaty of Lisbon «the EU seeks to establish a comprehensive strategy to achieve the objective of a high level of employment, involving all stakeholders». The Article 125 states that member states and the EU will work towards developing a coordinated strategy for employment. The Article 130 provides the establishment of employment committee with consultative status, to promote coordination of the policies of the member states in the field of employment and the labour market (The Lisbon Treaty, 2007).

These legal acts recorded current EU requirements for the modernization of higher education, which aims to ensure full employment by creating new jobs in the Member States, where highly-qualified workers have to come. Institutes of higher education and training should provide graduates with qualitative knowledge and qualifications required in the labour market.

The system of legal acts adopted by the EU institutions sets the direction for gradual convergence and harmonization of national educational systems of the member states relating to the internal market. Legal acts, mentioned above, show the EU attempt to form a supranational unified policy of training of students in accordance with the requirements of labour market, which is regulated primarily by supranational and national legislation.

Given this, it is important to analyze the legal regulation policy of training at national level. Thus, the legal acts are adopted by the European Parliament and the Council and they are common for the whole EU. They provide guidance which all member states in the EU should take into account when they issue their own laws. Accordingly, it raises a debate, and even the tension from the member states on the need to make changes in national legislation.

In Serbia, for example, there was a discussion on the necessity of changes in the existing law on higher education. According to the Law «Law on Higher Education for Republic of Serbia», national standards of higher education must comply with European standards, and accreditation procedures should meet the requirements of the European Higher Education. According to the Article 25 «higher education activities shall be carried out through academic and professional career courses based on the approved and/or accredited study programmes for acquiring higher edu- 
cation» (Law on Higher Education for the Republic of Serbia). These points fully correspond to the Resolutions of 1976, 1980, 1982, 1985 and the Council Recommendation 98/561/EC on European cooperation in quality assurance in higher education.

Unlike the Republic of Serbia, in the «Law on Higher Education» in the Republic of Poland there is a clear tendency for combination of higher education with labour market. Thus, according to Article 13 among the principal objects of a higher education institution is to "provide education which enables students to acquire and advance their knowledge as well as gain competencies necessary for professional life» (ACT of 27 July 2005, p. 19). To gain this objective, according to Article 4, HEIs should cooperate with businesses.

«Higher education institutions shall co-operate with the socio-economic environment, in particular by conducting research and development for business entities on the basis of organizationally and financially independent economic structures ... as well as through the involvement of employers' representatives in the development of study programmes and teaching processes» (ACT of 27 July 2005, p. 7).

It is important to note that the standards of education and training for certain branches should be determined by the minister of higher education.

«The minister competent for higher education, in consultation with the minister competent for health, shall determine, by regulation, the standards of education and training for the fields of study of medicine, dentistry, pharmacy, nursing and midwifery, while being mindful of the programme and training requirements necessary for the practice of the professions of a medical doctor, dentist, pharmacist, nurse and midwife, as provided for in the relevant legislation of the European Union» (ACT of 27 July 2005, p. 13).

In this context it is worth noting the requirements for teacher training, which are stated in Article 9c, «the minister competent for higher education in consultation with the minister for education shall, by regulation, determine the standards for the education and training of students preparing for the profession of a teacher, while being mindful of the demands of the labour market» (ACT of 27 July 2005, p. 14). Only employers' organization can nominate such demands who, based on Chapter 6, Articles 48-53a, must be part of the Polish Accreditation Committee (ACT of 27 July 2005, p. 54-60). This fully corresponds to the EU legislative acts on «European cooperation in providing high quality higher education».

Besides, it is worth paying attention to the following. To ensure the right conditions to prepare graduates for professional life in accordance with the demands of the labour market, universities are required to implement information services for professional orientation. These innovations embodied in legislative documents at the national level. Thus, in accordance with the «Decree promulgating the Labour Market Regulation Act (ZUTD)» of the Republic of Slovenia, Article 18 of «Lifelong career orientation», the following services shall «include activities enabling the identification of abilities, competencies and interests for making decisions in the field of employment, education, training and profession selection». Lifelong career orientation should provide information on the labour market; basic and in-depth consultation on the profession, as well as recommendations on skills for pupils, students and their parents (ZUTD). We consider that this Article, in detail construed the idea of providing consulting stakeholders that was described in the Resolutions of 1976, 1980, 1982, 1985.

An important extension of this is Article $19 \ll$ Providing labour market information». This service should include different types of information about opportunities for employment, education, training, financial assistance and other topics of the labour market in Slovenia and other EU countries. Any information should be provided for review with the labour market and transfer to it. These services in lifelong career orientation and labour market information should be provided in high school and universities (ZUTD).

In our opinion, the «Law on Higher Education» in the Republic of Poland and the «Decree promulgating the Labour Market Regulation Act (ZUTD)» of the Republic of Slovenia is the best example of legislation which is clearly apparent compliance with the norms of the European legislation on the training of students based on the interaction of higher education and training with labour market.

Based on an analysis of the EU legal acts, we can say that since Luxembourg European Council on 20-21 November 1997, which introduced the expansion of employment opportunities and the ability to adapt through education and training, in the legal acts are tried to reflect all relevant aspects, necessary for the modernization of higher education and for internal market work.

In legal documents is clearly seen direction for the transformation of higher education in order for its supply (graduates) answered market needs (working places). In this context we can trace this trend: first, legal acts regulated mutual recognition of diplomas, certificates and other formal evidence of qualifications (Resolution of 1974), improvement in preparation of young people for work and facilitation their transition from education to working life (Resolution of 1976, 1980, 1982, 1985), European cooperation in providing high quality of higher education $(98 / 561 / \mathrm{EC})$, then legal acts were adopted that form the foundations of efficiency and productivity of transnational mobility within the EU for education and training. Lisbon Treaty (2007) consolidated these issues at the level of the constitution.

Conclusion. The study indicates that today the EU is forming the policy of training students through cooperation of higher education with labour market, which is regulated by national and supranational law. The main feature of this policy compared with other areas of the EU is that this area is increasingly regulated by 
standardized legislation which provides the use of common approaches and standards.

It should be noted, that first of all, the process of preparing of graduates requires a unified approach, which should be provided to the needs of users of educational services as well as market opportunities. In this context it is also important to stress on the «market» approach to teacher training and its consequences. The changing nature of teaching and learning, which is a present feature in the EU will demand from teachers continuing education for career, perhaps even retraining. Besides, adult students will require different, more flexible, student-oriented types of education and training methods in the future.

In addition, on one hand, large investments in education and training, which are planned to be realized in Europe by 2020 will undoubtedly lead to the popularity of teaching profession and on the other hand, to responsibility because the teacher's role is crucial in creating a «knowledge economy» society. The demand for the teaching profession should increase at the labour market. Perhaps to increase the number of teachers and lecturers, whose percentage has decreased significantly due to demographic changes and low wages, the EU will need to increase wages to employees of education and to create appropriate working conditions (Мосьпан Н. В., 2014, с. 167).

The conclusions made here, point to a direct link of economic changes in the world with the changes in higher education and as a result in the teaching profession. The EU experience on this issue is a good example of current trends, which Ukraine should take into account to avoid the negative influence on students' training and teaching profession from globalization and marketization processes in education. In the future, the study of the EU policy of training students through cooperation of higher education with labour market has the great interest.

\section{References}

1. ACT of 27 July 2005 Law on Higher Education (Dziennik Ustaw). Official Journal of Laws of 2005, No.164, item 1365. Available at: http://www.nauka.gov.pl/g2/oryginal/2013_12/d687905792f5ff6a3ecf84d7df4f 8e57.pdf

2. 98/561/EC: Council Recommendation of 24 September 1998 on European cooperation in quality assurance in higher education. Available at: http://eur-lex.europa.eu/legal-content/EN/TXT/?qid=1466423507 695\&uri=CELEX:31998H0561

3. Council Resolution of 17 December 1999 on «Into the new millennium»: developing new working procedures for European cooperation in the field of education and training. Available at: http://eur-lex.europa.eu/ legal-content/EN/TXT/?qid=1466423507695\&uri=CELEX:32000Y0112(03)

4. Labour Market Regulation Act (ZUTD). Available at: https://www.ilo.org/dyn/natlex/docs/ELECTR ONIC/89477/102807/F-392019526/Labour\%20Market\%20Regulation.pdf

5. Law on Higher Education for the Republic of Serbia. Available at: http://www.minoritycentre.org/sites/ default/files/law-higher-education-serbia.pdf

6. Mos'pan N. V. (2014). Maybutnye profesiyi vchytelya v umovakh komertsializatsiyi vyshchoyi osvity $\mathrm{v}$ YeS [The future of the teaching profession in terms of the commercialization of higher education in the EU]. Visnyku ChNPU, \#119, 163-167 (ukr).

7. Ognevyuk V., Sysoieva S. (2015). Training of educational experts in Ukraine: experimental interdisciplinary program. The advanced science journal (6), pp. 98-103, DOI: 10.15550/ASJ.2015.06.098

8. Regulation (EEC) No 1612/68 of the Council of 15 October 1968 on freedom of movement for workers within the Community. Available at: http://eur-lex.europa.eu/legal-content/HR/ TXT/?uri=CELEX:31968R1612

9. Resolution of the Council and of the Ministers of Education, meeting within the Council, of 13 December 1976 concerning measures to be taken to improve the preparation of young people for work and to facilitate their transition from education to working life. Available at: http://eur-lex.europa.eu/legal-content/EN/TXT/?qid=14 66423507695\&uri=CELEX:41976X1230

10. Resolution of the Council and of the Ministers of Education meeting within the Council of 15 January 1980 concerning measures to be taken to improve the preparation of young people for work and to facilitate their transition from education to working life. Available at: http://eur-lex.europa.eu/legal-content/EN/TXT/?qid=14 66423507695\&uri=CELEX:41980X0130

11. Resolution of the Council and of the Ministers for Education, meeting within the Council, of 12 July 1982 concerning measures to be taken to improve the preparation of young people for work and to facilitate their transition from education to working life. Available at: http://eur-lex.europa.eu/legal-content/EN/TXT/?qid=14 66423507695\&uri=CELEX:41982X0728

12. Resolution of the Council and of the Ministers for Education, meeting with the Council of the 5 December 1985 extending for one year certain measures taken to improve the preparation of young people for work and to facilitate their transition from education to working life. Available at: http://eur-lex.europa.eu/legal-content/ EN/TXT/?qid=1466423507695\&uri=CELEX:41985X1218 
13. The Lisbon Treaty. Title XII - Education, vocational training, youth and sport. Article 165-166. Available at: http://www.lisbon-treaty.org/wcm/the-lisbon-treaty/treaty-on-the-functioning-of-the-european-unionand-comments/part-3-union-policies-and-internal-actions/title-xii-education-vocational-training-youth-andsport.html

\section{ТЕНДЕНЦИИ ПОДГОТОВКИ СТУДЕНТОВ В ЕВРОПЕЙСКОМ СОЮЗЕ: НОРМАТИВНО-ПРАВОВОЙ АСПЕКТ}

Мосьпан Наталия, кандидат педагогических наук, доцент, доцент кафедры английской филологии и перевода, Киевский университет имени Бориса Гринченко, ул. Тимошенко, 13-б, 04212 г. Киев, Украина, n.mospan@kubg.edu.ua

В статье представлены современные тендениии в процессе подготовки студентов высших учебных заведений в Европейском Союзе. Данные тенденции выявлены на основе анализа нормативно-правовых документов (законодательных актов первичного и вторичного права), в которых отражена реакция Европейского Союза на современные мировые изменения в образовании: глобализации и маркетизации. Эти процессы требуют от высшего образования внедрять новые подходы к подготовке студентов с учетом требований рынка труда. Учитывая это, автором особое внимание уделяется процессу подготовки учителей.

Ключевые слова: высшее образование; Европейский Союз; законодательные акты; подготовка студентов; рынок труда.

\section{ТЕНДЕНЦІї ПІДГОТОВКИ СТУДЕНТІВ У ЄВРОПЕЙСЬКОМУ СОЮЗІ: НОРМАТИВНО-ПРАВОВИЙ АСПЕКТ}

Мосьпан Наталія, кандидат педагогічних наук, доцент, доцент кафедри англійської філології та перекладу, Київський університет імені Бориса Грінченка, вул. Тимошенка, 13-б, 04212 м. Київ, Україна, n.mospan@kubg.edu.ua

У статті представлені сучасні тенденції в процесі підготовки студентів вищих навчальних закладів в Європейському Союзі. Реакція вищої освіти на глобальні зміни (глобалізацію та маркетизацію)) у світі була відображена у важливих законопроектах, деклараціях, договорах та актах вторинного права, які лягли в основу нормативно-правового регулювання політики взаємодї вищої освіти з ринком пращі в СС. Важливим елементом иієї політики є процес підготовки студентів вищих навчальних закладів, особливо процес підготовки вчителів, оскільки їх функція виграє значну роль у формуванні нового покоління «суспільства знань». Відповідно зміни у вищій освіті першочергово вплинули на процес підготовки студентів вищих навчальних закладів, що й було закріплено на законодавчому рівні СС. У законодавчих актах від вищої освіти вимагають впроваджувати нові підходи до підготовки студентів з урахуванням вимог ринку праці. Автором проаналізовано Постанови Ради та Міністрів освіти 1976, 1980, 1982 та 1985 років «Про поліпшення підготовки молодих людей для роботи та для полегшення їх переходу від освіти до трудового життя», які є правовою базою початку формування сучасної політики підготовки фахівців, основаної на взаємодії вищої освіти з ринком праці. Вони вказують на спробу ЄС сформувати наднаціональну уніфіковану політику в області підготовки студентів відповідно до вимог ринку пращі. Здійснено вивчення нормативно-правового регулювання політики підготовки студенів на національному рівні. Зроблено висновок, що у нормативно-правових документах $C С$ та держав-иленів чітко простежується напрям трансформацї вищої освіти для того, щоб ї̈ пропозичія (випускники) відповідала ринковим потребам (робочі місия).

Ключові слова: вища освіта; Європейський Союз; законодавчі акти; підготовка студентів; ринок nрачі.

Стаття надійшла до редакції 16.09.2016

Прийнято до друку 27.10.2016 